\title{
Postharvest Changes in Physicochemical Properties and Levels of Some Inorganic Elements in Sugar Apple (Annona squamosa L.) Fruits of Coast Region, Tanzania
}

\author{
Esther Hellen Lugwisha ${ }^{1,}$, Christina Fabian², Othman Chande Othman ${ }^{1}$ \\ ${ }^{1}$ Chemistry Department, University of Dar es Salaam, Dar es Salaam, Tanzania \\ ${ }^{2}$ Chemistry Department, Mkwawa University College of Education, Iringa, Tanzania \\ Email address: \\ elugwisha@gmail.com (E. H. Lugwisha),Tina84f@yahoo.com (C. Fabian),o_chande@yahoo.co.uk (O. C. Othman) \\ ${ }^{*}$ Corresponding author
}

\section{To cite this article:}

Esther Hellen Lugwisha, Christina Fabian, Othman Chande Othman. Postharvest Changes in Physicochemical Properties and Levels of Some Inorganic Elements in Sugar Apple (Annona squamosa L.) Fruits of Coast Region, Tanzania. Journal of Food and Nutrition Sciences. Vol. 4, No. 3, 2016, pp. 41-48. doi: 10.11648/j.jfns.20160403.11

Received: April 20, 2016; Accepted: April 28, 2016; Published: May 11, 2016

\begin{abstract}
The physicochemical composition of sugar apple (Annona squamosa L.) fruits from Kibaha, Coast Region during open air storage ripening process were determined. The ash, titratable acidity, crude fat, crude fiber, moisture and sugars content were determined by proximate analysis. Ascorbic acid contents were determined using the 2,6-dichlorophenol-indophenol dye method while mineral elements and heavy metals were determined by Flame Atomic Absorption Spectrophotometry (FAAS). The fruits were always harvested at the mature stage and allowed to ripen during open air storage. The determinations were done immediately after arrival at the laboratory and thereafter at intervals of two days from the day of harvest to the 8th day. The results showed that fresh sugar apple fruits had high moisture content range of $(64 \%-73 \%)$, low titratable acidity $(<0.28 \%$ ca), low crude fat $(0.51 \mathrm{~g} / 100 \mathrm{~g}$-fw), high ash content $(1.44 \mathrm{~g} / 100 \mathrm{~g}$-fw), low crude fibre content $(0.185 \mathrm{~g} / 100 \mathrm{~g}$-fw), high ascorbic acid content (51-34 mg/100 g-fw), high total sugars content (49.7\% - 31.1\%), moderate reducing sugar content ( $43.17 \%-18.57 \%)$ and sucrose content $(11.8 \%-0.9 \%)$. Of the mineral elements $(\mathrm{K}, \mathrm{Ca}$ and $\mathrm{Na}$ ) determined, the highest content was of $\mathrm{Ca}(2838.82$ $\mathrm{mg} / 100 \mathrm{~g}$-fw.). Heavy metals ( $\mathrm{Fe}, \mathrm{Zn}, \mathrm{Cu}, \mathrm{Pb}$ and $\mathrm{Cd}$ ) content was very low in the sugar apple fruits, ranging between $<0.0015$ $\mathrm{mg} / 100 \mathrm{~g}$-fw for $\mathrm{Cd}$ and $1.27 \mathrm{mg} / 100 \mathrm{~g}$-fw for Fe. Except for acidity and ascorbic acid contents which were decreasing during storage ripening, the moisture content, total sugar content, reducing sugar content and sucrose were all increasing as the fruit was ripening while in storage. There were no significant changes during storage ripening for levels of crude fat, ash, minerals and heavy metals. The results of this study suggest that these fruits could highly contribute in the improvement of the nutrition of consumers.
\end{abstract}

Keywords: Sugar Apple, Annona squamosa L., Physico-Chemical, Proximate Analysis, Fruits, Storage Ripening, Macronutrients, Tanzania

\section{Introduction}

Sugar apple (Annona squamosa L.) a well-branched tree or shrub from the family Annonaceae that bears edible fruits has several common names such as custard apple (Indian) anon (Spanish) and sweetsop (English). In Tanzania (Swahili) it is known as "topetope" widely distributed throughout the regions but mostly grows in wet lowland savannah by the coast, in the Usambara area and in Lake Victoria basin.
Generally the fruit of sugar apple looks round in shape, but pine cone like having $2.5-4 \mathrm{~cm}$ in diameter. The flesh sugar apple fruit is very sweet to taste and pleasant, white to light yellow, and tastes like custard. It has a very discrete, sweet-smelling fragrance. Due to its high respiration rate, sugar apple has an extremely limited post-harvest shelf life, making handling, storage and distribution, key issues for 
growers [1]. It softens very rapidly during ripening and becomes difficult to consume fresh [2]. Lately, sugar apple fruit has been widely used by industry due to its flavor and high concentrations of titratable acidity, which is particularly important for fruit processing reducing the addiction of artificial acid components [3].

Sugar-apple fruits are important fruits in nutrition because they are of great benefit to the human diet as they are high in energy, excellent source of manganese; contain anti-oxidants like vitamin $\mathrm{C}$ which helps to fight free radicals in our body, good source of thiamine and vitamin $\mathrm{B} 6$, and provide vitamin B2, B3 B5, B9, iron and phosphorus in fair quantities. These fruits are also high in potassium and magnesium that protect our hearts from cardiac disease and control blood pressure. They are also known to be great for eyes, and cures indigestion problems [4]. The unripe green fruit has been used to treat diarrhea and dysentery while the ripe fruits are reported to treat tumors [5].

Because of the importance of these fruits, scientific studies that characterize these species in relation to quality and maturation of fruits have to be undertaken. In this sense, the determination of physicochemical characteristics of fruits constitutes an important reference for studies about the maturation and quality of fruits, with the ultimate aim of determining consumer acceptance requirements. As such this study was undertaken.

Several research studies which have been undertaken on the physicochemical composition of Tanzanian fruits include those on mangoes [6], papaya [7], pineapples [8], soursop [9], pomegranate [10] and oranges [11]. So far little attention has been paid to sugar apples grown in Tanzania and there is no reliable information about physicochemical characteristics of these fruits in scientific literature, including books and manuscripts. Mineral elements and heavy metal toxicity has provoked considerable research in the analysis of food and food products [12]. Although, macro- and microelements are valuable for diseases and disorders control in man, they could however, produce harmful effects in excessive amounts [13]. Some heavy metals like cadmium, lead and mercury are major contaminants of food supply and may be considered the most dangerous elements to our environment while others like iron, zinc and copper are essential for biochemical reactions in the body [14].

This study therefore reports on the proximate composition (moisture, acidity, sugars, ash, crude fibers and crude fat content), ascorbic acid content, mineral elements and heavy metals content in sugar apple fruits of Coast Region, Tanzania.

\section{Material and Methods}

\subsection{Reagents}

The following analytical grade reagents were used in this study: hydrochloric acid (assay $37 \mathrm{w} / \mathrm{v}$, specific gravity 1.2), sulfuric acid (assay 95-98 w/v, specific gravity 1.840) and standard ascorbic acid (assay 99.7\%) as supplied by Aldrich Chemical Company Ltd, England. Copper sulfate (99\%) was obtained from Lab Tech chemicals Ltd and sodium hydroxide pellets (assay 97\%) were obtained from Techno Pharmchem India. 2,6-dichlorophenol-indophenol A.C.S. reagent and phenolphthalein indicator used were supplied by LOBAL Chemie Company. Potassium and sodium tartrate (assay 99\%) and citric acid (monohydrate) assay $99.8 \%$ were supplied by Riedel-de Haen AG and ethanol (assay 95\% pure) was supplied by CARLO ERBA reagents of Italy. Acetic acid (glacial assay 99.5\%), nitric acid, perchloric acid, metaphosphoric acid (assay 88\% w/w) and methylene blue indicator as obtained from B.D.H Ltd, England. Lead acetate (assay < 99\%), potassium oxalate (assay 99.5\%) and phenolphthalein indicator ( $\mathrm{pH}$ range 8.3-10) were obtained from May \& Baker Ltd. Dagenham, England. Petroleumether (bp $60-80^{\circ} \mathrm{C}$ ) was obtained from the Central Drug House Ltd. of India. Deionized distilled water was used for all needed dilutions.

\subsection{Instruments and Equipment}

An electronic balance Mettler Toledo model B 303-S, a Genlab oven supplied by Wideness Cheshire Ltd. having a temperature range of 0 to $250^{\circ} \mathrm{C}$ and a muffle furnace, Gallenkamp Rapid Model, from Gallenkamp Ltd, having a heating temperature range up to $1000^{\circ} \mathrm{C}$ were used. The Gallenkamp Centrifuge model 200 with frequency of $50 \mathrm{~Hz}$ from Gallenkamp Ltd, Osterizer blendor model 867-66A, an IKAMAG-RET type hot plate, a HANNA waterproof $\mathrm{pH}$-meter, a heating mantle of one litre, a soxhlet apparatus and the Flame Atomic Absorption Spectrophotometer, model iCE 3000 v1.3 instrument were also used.

\subsection{Fruit Sample Collection}

Samples of sugar apple fruits were collected from Kibaha farms in Coast Region. Fully matured fruits that had no signs of wound or damage were picked directly from trees and were transported to the Chemistry Department laboratory, University of Dar es Salaam, for open-air, room temperature storage ripening experiments and for further preparations and analysis.

\subsection{Analysis}

The following determinations were done in triplicate immediately after arrival of the fresh fruits at the laboratory and thereafter at intervals of two days from the day of harvest to the 8 th day.

\subsubsection{Moisture Content}

A clean porcelain crucible was dried in an oven at $110^{\circ} \mathrm{C}$ for $1 \mathrm{~h}$, cooled in a desiccator and weighed. About $20 \mathrm{~g}$ of fresh fruit sample were spread in the crucible, weighed as quickly as possible to determine its exact weight and dried in a hot air oven at $70^{\circ} \mathrm{C}$ for $16 \mathrm{~h}$. This was then followed by cooling in a desiccator and weighing until a constant weight was attained. The moisture determination for each sample was done in triplicate and the average value recorded as percent moisture [15]. 


\subsubsection{Titratable Acidity}

$10 \mathrm{~g}$ of the minced fresh fruit sample were mixed with 200 $\mathrm{mL}$ of distilled water and boiled for $1 \mathrm{~h}$. The mixture was cooled, filtered and the filtrate transferred to a $250 \mathrm{~mL}$ volumetric flask and made up to the mark. $10 \mathrm{~mL}$ of the filtrate was titrated with $0.1 \mathrm{M} \mathrm{NaOH}$ using $1 \%$ phenolphthalein solution as indicator. The results were expressed as \% citric acid [15]. All determinations were done in triplicate and the average values were recorded.

\subsubsection{Ash Content}

$5.0 \mathrm{~g}$ of the sample were placed in a dry porcelain crucible, dried in a hot air oven for $16 \mathrm{~h}$. The dried sample was placed in a muffle furnace and ashed at temperature of around $525^{\circ} \mathrm{C}$ for $6 \mathrm{~h}$. The ash was then cooled in a desiccator and weighed. The weight was recorded as $g$ per $100 \mathrm{~g}$ fresh weight ( $\mathrm{g}-\mathrm{fw}$ ) [15]. The determination was done in triplicate and the average value was recorded.

\subsubsection{Crude Fat}

The weighed dried fruit sample was put into a thimble and covered with fat free cotton. The thimble was then put into the soxhlet apparatus. The flask was filled with $150 \mathrm{~mL}$ petroleum ether and extraction was done for $16 \mathrm{~h}$. At the end the sample was dried at $100^{\circ} \mathrm{C}$ in an oven for $1 \mathrm{~h}$, then cooled to room temperature and re-weighed. The difference in the weights gave the fat-soluble material present in the sample. Determinations were done in triplicate and the average value was recorded [15].

\subsubsection{Crude Fibers}

$2 \mathrm{~g}$ of residue remaining from the crude fat determination was poured in a digestion flask followed by $200 \mathrm{~mL}$ of boiling $0.1275 \mathrm{M}$ sulfuric acid. The mixture in the flask was immediately connected to a condenser and the mixture heated for $30 \mathrm{~min}$. The material was then filtered and washed thoroughly with boiling distilled water until the washings were no longer acidic. A $0.313 \mathrm{M} \mathrm{NaOH}$ solution was boiled under reflux and the washed material added to it. The content in the flask were connected to the reflux condenser and boiled for $30 \mathrm{~min}$. The material was then filtered in a filtering cloth in a fluted funnel and washed thoroughly with distilled water followed by $15 \mathrm{~mL}$ of alcohol. The contents were finally dried at $110^{\circ} \mathrm{C}$ to a constant weight, cooled in a dessicator and weighed. The material was then ashed. The loss in weight represents the crude fiber amount of the fruit. The procedure of Ranganna [15] was followed.

\subsubsection{Sugars}

The reducing sugar in the fruits were determined by titration method where clarified fruit solution was titrated against mixed Fehling's solution using methylene blue as an indicator. Total sugar was also determined by titration but before titration there was an addition of citric acid and the solution was boiled in order to complete the inversion of sucrose. Total sugars, reducing sugars and sucrose content in the sugar apple fruits were determined following the procedures of method 932.12 of AOAC [16].

\subsubsection{Ascorbic Acid}

$5 \mathrm{~g}$ of fresh fruit sample were blended with $25 \mathrm{~mL}$ of $5 \%$ metaphosphoric acid solution. The mixture was filtered through a Whatman No. 42 filter paper. The residue was then washed with $5 \%$ metaphosphoric acid until the total volume of the collected filtrate was $50 \mathrm{~mL}$. The filtrate was then centrifuged at 2000 r.p.m for $20 \mathrm{~min} .10 \mathrm{~mL}$ of the clear filtrate was pipetted in to a conical flask and titrated against a $0.025 \%$ 2,6-dichlorophenol-indophenol reagent. The titration was done in triplicate and the average titre value was recorded. The $0.025 \%$ 2,6- dichlorophenol- indophenol reagent was standardized using standard ascorbic acid solution as described by AOAC [16].

\subsection{Mineral Elements and Heavy Metals}

\subsubsection{Sample Preparation}

$1.0 \mathrm{~g}$ of a well dried and powdered fruit sample was placed in a digestion bottle followed by addition of $8 \mathrm{~mL}$ conc. nitric acid and $2 \mathrm{~mL}$ perchloric acid. The solution was then heated for about 4 hours with slow addition of drops of perchloric acid until a clear solution was obtained. The solution was then transferred to a $50 \mathrm{~mL}$ volumetric flask and made up to the mark by distilled water. Appropriate dilutions were done for elements present at high concentrations.

\subsubsection{Atomic Absorption Spectrophotometry (AAS)}

All determinations of metals were performed with the iCE 3000 v1.3 AAS instrument. Hollow cathode lamps of the different metals were used as radiation sources for the instrument. The instruction manual of the instrument was used as guide for all measurements. Calibration standards were first aspirated into the AAS to calibrate the instrument and check its linearity response. After all necessary set up, standardization and calibration procedures had been completed then the above treated fruit juice sample solutions were aspirated into the AAS instrument for precise measurement of metal concentration. All determinations, in triplicate, were performed at the laboratory of the Chemistry Department, University of Dar es Salaam.

\section{Results and Discussion}

The experimental results on proximate compositions (moisture, acidity, reducing sugars, total sugars, sucrose) and ascorbic acid content of sugar apple (Annona squamosa L.) fruit are reported in Table 1. The results on determinations of ash, crude fat and crude fibre content are reported in Table 3. The results of determinations of mineral elements and heavy metals are reported in Table 4. All results are average results of triplicate determinations. The comparative data of physicochemical studies of sugar apple reported by other researchers is presented in Table 2.

\subsection{Moisture Content}

Sugar apple fruits from Kibaha in the Coast Region showed an increase in moisture content from $64 \%$ at harvest to $73 \%$ by the 8th day of storage ripening (Table 1). A sharp increase in 
moisture was noted from the day of harvest to the 2 nd day then a gradual increase followed. The high moisture content $(64 \%$ to $73 \%$ ) observed in these fruits implies that the fruits have a short shelf life [17]. The fruits would need to be stored in a cool condition if they are to be kept for a long period or would be needed to be processed as quickly as possible to avoid microbial spoilage [17]. An increase in moisture content during storage ripening has been reported in other Tanzanian fruits like mangoes [6] and papaya [7]. Increase in moisture content during ripening could be accounted for the loss of dry matter which is a decrease in total carbohydrate. During ripening there is an enzymatic breakdown of the polysaccharides in the fruits, the breakdown of these natural polymers to mostly sugars is then the cause of the decrease in firmness of the fruit and the increase in moisture content [18]. However, the moisture content of sugar apple fruits observed in this study is lower than that of Hawaii sugar apple fruits $75.97 \%$ reported by Carey and Nao [19].

Table 1. Proximate composition (moisture, acidity, reducing sugars, total sugars, sucrose) and ascorbic acid content of sugar apple (Annona squamosa L.) fruits of Coast Region, Tanzania.

\begin{tabular}{|c|c|c|c|c|c|}
\hline Storage-ripening days Parameter $(n=3)$ & $\mathbf{0}$ & 2 & 4 & 6 & 8 \\
\hline Moisture (\%) & $64.0 \pm 2.1$ & $68.3 \pm 2.2$ & $70.2 \pm 1.1$ & $71.6 \pm 3.2$ & $73.1 \pm 3.1$ \\
\hline Titratable acidity (\%) & $0.28 \pm 0.03$ & $0.23 \pm 0.01$ & $0.19 \pm 0.02$ & $0.15 \pm 0.02$ & $0.12 \pm 0.02$ \\
\hline Reducing sugars $(\%)$ & $18.6 \pm 1.6$ & $24.4 \pm 1.9$ & $37.5 \pm 2.3$ & $40.0 \pm 3.8$ & $43.2 \pm 4.2$ \\
\hline Total sugars $(\%)$ & $31.1 \pm 2.0$ & $35.9 \pm 3.7$ & $42.2 \pm 4.8$ & $46.3 \pm 2.9$ & $49.7 \pm 2.8$ \\
\hline Sucrose $(\%)$ & $0.9 \pm 0.1$ & $4.3 \pm 0.4$ & $6.2 \pm 0.8$ & $8.7 \pm 1.2$ & $11.8 \pm 2.4$ \\
\hline Ascorbic acid (mg/100 g-fw) & $51.1 \pm 3.1$ & $50.7 \pm 1.1$ & $43.0 \pm 2.3$ & $39.3 \pm 2.2$ & $34.1 \pm 3.3$ \\
\hline
\end{tabular}

\subsection{Titratable Acidity}

In sugar apple fruits a decrease in titratable acidity $0.28-$ $0.12 \%$ was observed during storage ripening of the fruits (Table 1). This reduction of acidity might be due to utilization of constituent acids in the respiratory process [20]. This behaviour has also been reported by Vishnu et al. [21] for sugar apple, Maiman and Ahmad [22] and Lugwisha et al. [10] for pomegranate fruits. At the time of picking, the sugar apple fruits had $0.28 \%$ malic acid (ma) while by the 8 th day of storage they had $0.12 \%$ ma (Table 1). These values are comparable to the value of $0.25 \%$ ma for sugar apple fruits of China reported by Tien et al. [1]. However, these values of acidity in sugar apple, are lower than the values of $0.51 \%$ for Indian sugar apples [23], $0.95-1.5 \%$ citric acid for Tanzanian pineapple fruits [8] and Tanzanian soursop values of 0.192 $1.248 \%$ [9] but higher than the values of $0.08-0.18 \%$ ca for Tanzanian papaya fruits [7].

\subsection{Sugars}

An increase in the content of all three types of sugars was observed during storage ripening of sugar apple fruits (Figure. 1). Similar observations were noted for Tanzanian soursop fruits [9]. Since the two fruits are in the same family, the reason for the increase in their sugar content may also be the same which could be due to the enzymatic break down of polysaccharides into sugars. Such observation has also been reported by Juceliandy et al. [24] for Brazilian sugar apple fruits. The sugar apple fruits in this study had an initial total sugars content of $31.05 \%$ at harvest and this increased to $49.70 \%$ by the 8 th day of storage ripening (Table 1). These values are higher than the value $32 \%$ for Asian sugar apple fruits reported by Trang et al. [25]. Reducing sugars content ranged from $18.57 \%$ - 43.17 (Table 1). These values are high compared to the value $8.6 \%$ for United Kingdom's annona species fruits reported by Pinto et al. [26].

Sucrose content in fully ripened sugar apple fruits was $11.81 \%$ (Table 1 ). This value is higher than the value of $7.82 \%$ reported for Columbia sugar apple fruits [27].

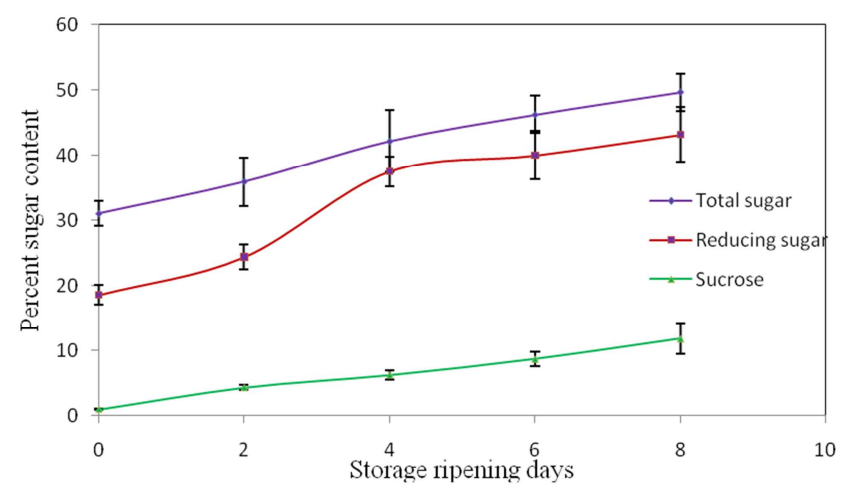

Figure 1. Sugar content in sugar apple fruits during storage ripening.

\subsection{Ascorbic Acid}

In the studied sugar apple fruits ascorbic acid content decreased from $51 \mathrm{mg} / 100 \mathrm{~g}$ to $34 \mathrm{mg} / 100 \mathrm{~g}$-fw (Table 1). Similar observations were noted for Tanzanian soursop fruits [9] and pomegranate fruits [10]. The range in the studied sugar apple fruits is lower than the values of $50-60 \mathrm{mg} / 100 \mathrm{~g}$ for Indian sugar apple fruits reported by Pareek et al. [28]. However, the ascorbic acid level is also lower than the recommended nutrient intake (RNI) of $75 \mathrm{mg}$ per day given by FAO/WHO [29].

Ascorbic acid is the least stable of the water soluble vitamins. It is readily oxidized to dehydro-1-ascorbic acid by the enzyme ascorbic acid oxidase [30] found in fruits. This oxidation reaction is a function of temperature, $\mathrm{pH}$, presence of metal ions such as copper and iron and oxygen content in fruits thus the decrease in the content of the ascorbic acid observed in these fruits during storage ripening might be due to this reaction.

A comparative look at the results of physicochemical studies of sugar apple reported by other researchers is presented in Table 2. The results show a wide variation of the values for the different parameters as the fruits are grown in 
different soils, climates and geographical locations. The percent moisture content ranges between 3.96 (Mumbai) [35] to 75.97 (Hawaii) [19], the percent acidity varies from 0.055 (Vietnam) [36] to 0.51 (India) [23], the percent total sugars content varies from 6.25 (Vietnam) [36] to 32 (Asia) [25], the reducing sugars from 5.36 (Vietnam) [36] to 20.75 (India) [23], sucrose varies from 0.93 (Tanzania) [this study] to 7.82 (Columbia) [27], and ascorbic acid content varies from 9.22 (India) [23] to $60 \mathrm{mg} / 100 \mathrm{~g}$-fw (India) [28].

\subsection{Ash}

The ash content of sugar apple fruits measured in this study was $1.44 \mathrm{~g} / 100 \mathrm{~g}-\mathrm{fw}$ (Table 3). This value is high when compared to the value of $0.7 \mathrm{~g} / 100 \mathrm{~g}$-fw obtained for Florida sugar apple fruits reported by Leal et al. [38] and also higher than $0.87 \mathrm{mg} / 100 \mathrm{~g}$-fw and $0.35 \mathrm{~g} / 100 \mathrm{~g}$-fw reported for Tanzanian soursop [9] and pomegranate [10], respectively. This is probably due to the high mineral element content such as reported in Table 4 . The main purpose of ash determination is to assess the quality of the food materials. High total ash content in a food material signifies the presence of adulterants [15]. The ash content is a measure of the total amount of minerals such as sodium, potassium and iron present within food. Although annona fruits are relatively poor sources of proteins and vitamins, their high mineral content makes them ideal dietary sources of electrolytes.

Table 2. Comparative data on proximate composition and ascorbic acid content of sugar apple (Annona squamosa L.) fruits.

\begin{tabular}{lll}
\hline Attribute & This study & Literature \\
\hline Moisture (\%) & $64.01 \pm 2.1$ & $\begin{array}{l}70.8[4], 75.97[19], 75.66[31], 70 \\
{[32], 6.4[33], 6.7[34], 3.73-3.96}\end{array}$ \\
& & {$[35]$} \\
Titratable acidity (\%) & $0.28 \pm 0.03$ & $0.25[1], 0.51[23], 0.055[36]$, \\
Reducing sugars (\%) & $18.57 \pm 1.56$ & $20.75[23], 8.6[26], 5.36[36]$, \\
Total sugars (\%) & $31.05 \pm 1.96$ & $21.42[23], 32[25], 6.25[36]$, \\
Sucrose (\%) & $0.93 \pm 0.12$ & $7.82[27]$ \\
$\begin{array}{l}\text { Ascorbic acid } \\
\text { (mg/100 g -fw) }\end{array}$ & $51.1 \pm 3.12$ & $9.22[23], 50-60[28]$, \\
\hline
\end{tabular}

Table 3. Ash, crude fat and crude fiber content in sugar apple (Annona squamosa L.) fruits of Coast Region, Tanzania.

\begin{tabular}{lll}
\hline \multirow{2}{*}{ Attribute } & \multicolumn{2}{l}{ Concentration (mean \pm SD in g/100 g-fw) } \\
\cline { 2 - 3 } & This study $\mathbf{n}=\mathbf{3}$ & Literature \\
\hline \multirow{2}{*}{ Ash } & $1.44 \pm 0.23$ & $0.57[4], 0.25[31], 7.47[32], 1.77[33]$, \\
& & $2.2[34], 3.94[35], 0.7[38]$ \\
\multirow{2}{*}{ Crude fat } & $0.51 \pm 0.14$ & $0.067[4], 0.57[19], 1.56[31], 11.5$ \\
& & {$[32], 28.3[33], 27.8[34], 1.56[37]$,} \\
\multirow{2}{*}{ Crude fiber } & $0.18 \pm 0.09$ & $0.31[39]$ \\
& & $2.78[4], 7.53[31], 46.30[32], 17.6$ \\
\end{tabular}

fw-fresh weight

\subsection{Crude Fat}

The crude fat content of sugar apple fruits was $0.51 \pm 0.14$ $\mathrm{g} / 100 \mathrm{~g}$ (Table 3 ). This value is almost similar to the value of $0.57 \mathrm{~g} / 100 \mathrm{~g}$ reported for Hawaii sugar apple fruits by Carey and Nao [19] and higher than $0.31 \mathrm{~g} / 100 \mathrm{~g}$ reported for
Brazilian carambola fruits by Narian et al. [39]. However, this value is much lower than the values reported by other researchers [31-34, 37] The low crude fat content in fruits in the present study shows that fats are mobilized and stored in seeds and agrees with the observation that these fruits are not good source of energy [40]. These fruits are recommended for loss or maintaining of weight and are known to improve blood lipids and pressure [4].

\subsection{Crude Fiber}

The average crude fiber content in the sugar apple fruits observed in this study was $0.185 \pm 0.09 \mathrm{~g} / 100 \mathrm{~g}$ (Table 3 ). This value is less compared to values of sugar apple fruits reported by $[4,31-34,37,41]$ and also less than $0.98 \mathrm{~g} / 100 \mathrm{~g}$ of Brazilian carambola fruits reported by Narian et al. [39].

Fiber helps to maintain the health of the gastrointestinal tract and is used in weight regulation [42] but in excess it may bind trace elements, leading to deficiency of some of the micro nutrients in the body like iron and zinc [43]. High fibre content makes fruits ideal food that could be harnessed in the control of cholesterol absorption hence protect against coronary heart disease risks. The high fibre content could also be harnessed in the control of blood glucose levels in normal and diabetic individuals thereby protecting man against excessive weight gain and obesity and its associated diseases [43].

\subsection{Macro-elements}

Mineral elements are vital for the maintenance of our body health. Those that are required in our diet in large amounts $(>100 \mathrm{mg} /$ day) are known as macro elements and those that are required in small amount $(<100 \mathrm{mg}$ /day) are known as trace or micro-elements. Macro elements which include $\mathrm{Na}, \mathrm{K}$, $\mathrm{Ca}, \mathrm{Mg}$ and $\mathrm{P}$ have multiple roles within the body such as initiation of hormone production and speed up of the metabolic processes. Trace elements which include $\mathrm{Fe}, \mathrm{I}_{2}, \mathrm{Cu}$, $\mathrm{Zn}, \mathrm{Cr}$ and $\mathrm{Mn}$ interact with vitamins and macro elements to enhance their effects on the body. However, the presence of these elements above permissible levels can cause various consequences.

The levels of sodium, potassium and calcium in the fruits observed are summarized in (Table 4). The variation of levels of these minerals could be due to differences in the levels of the elements present in the soil and the different rates of absorption of these elements by plants which in turn is influenced by the $\mathrm{pH}$ of the soil, interactions with soil colloids, microbial activity and soil physical conditions such as aeration, compaction, temperature, moisture and the organic matter content [44].

The average calcium content in sugar apple fruits of Coast Region was $2838.82 \pm 98.99 \mathrm{mg} / 100 \mathrm{~g}$-fw (Table 4) a value that is much higher than $60.25 \mathrm{mg} / 100 \mathrm{~g}$-fw for Indian sugar apple fruits reported by Bhardwaj et al. [4] and $450 \mathrm{mg} / 100$ g-fw for Nigerian sugar apple reported by Hassan et al. [32]. This high value of calcium compares well with the body requirements for the dietary calcium which is $2500 \mathrm{mg}$ /day [45] thus $100 \mathrm{~g}$ of Coast sugar apple fruits may suffice for this 
need in a day. The high value of calcium in these fruits can be attributed to many factors. Probably the calcium content in the soil of the sampling area was high such as the amount available for absorption in this fruits was also high and may also be due to addition of fertilizers especially for maize cultivation in the Kibaha farms where the fruits were collected.

The average potassium content in the sugar apple fruits was $873 \pm 203.63 \mathrm{mg} / 100 \mathrm{~g}-\mathrm{fw}$ (Table 4 ). This value is higher than the value of $45 \pm 0.49 \mathrm{mg} / 100 \mathrm{~g}-\mathrm{fw}$ for Nigeria sugar apple fruits [32] but much lower than the value of $8280 \mathrm{mg} / 100 \mathrm{~g}-\mathrm{fw}$ reported for Nigerian custard apple fruits [31]. However, the amount of potassium in the fruits in this study can be said to be low since they can contribute very little to the recommended daily allowance (RDA) for potassium which is $2000 \mathrm{mg}$ /day for an adult [45].

The highest level of sodium found in sugar apple fruits was $1384.56 \pm 73.68 \mathrm{mg} / 100 \mathrm{~g}$-fw. The concentration of sodium in sugar apple is very high compared to the level $10.00 \mathrm{~g} / 100 \mathrm{~g}$ found in sugar apple fruits of Nigeria reported by Hassan et al. [32] and $675.79 \pm 436.88 \mathrm{mg} / 100 \mathrm{~g}$-fw found in pomegranate fruits [10]. However, this value is less compared to 7310 $\mathrm{mg} / 100 \mathrm{~g}-\mathrm{fw}$ for Nigerian custard apple fruits reported by Amoo et al. [31]. These fruits can contribute in a large quantity the amount of sodium needed in the body since RDA value for sodium for an adult is $500 \mathrm{mg}$ [45]. On the other side, high sodium content makes them not to be ideal food material for prevention and management of hypertension.

Table 4. Mineral element and heavy metal content in sugar apple (Annona squamosa L.) fruits of Coast Region, Tanzania.

\begin{tabular}{lll}
\hline \multirow{2}{*}{ Minerals } & \multicolumn{2}{l}{ Concentration $(\mathbf{m e a n} \pm$ SD in $\mathbf{g} / \mathbf{1 0 0}$ g-fw) } \\
\cline { 2 - 3 } & This study $\mathbf{n}=\mathbf{3}$ & Literature \\
\hline Macro element & & \\
Calcium & $2838.82 \pm 98.99$ & $60.25[4], 4130[31], 450[32]$ \\
Sodium & $1384.56 \pm 73.68$ & $7310[31], 10[32]$, \\
Potassium & $873.25 \pm 203.63$ & $8280[31], 45[32]$, \\
Heavy metals & & \\
Iron & $1.27 \pm 0.54$ & $4.808[4], 1.70[32]$, \\
Zinc & $0.51 \pm 0.10$ & $2.868[4], 300[31], 0.30[32]$ \\
Copper & $0.12 \pm 0.07$ & $0.95[4], 0.02[32]$, \\
Lead & $0.13 \pm 0.03$ & ND [32] \\
Cadmium & ND* & $<0.0017[4]$ \\
\hline
\end{tabular}

*ND: Not Detected i.e. $<0.0015 \mathrm{mg} / 100 \mathrm{~g}-\mathrm{fw}$

\subsection{Heavy Metal Content}

Heavy metals such as $\mathrm{Fe}, \mathrm{Co}, \mathrm{Cu}, \mathrm{Mn}, \mathrm{Mo}$ and $\mathrm{Zn}$ are required by our bodies in varying amounts. However, in higher levels they are toxic and can be damaging to the organism. Other heavy metals such as $\mathrm{Pb}, \mathrm{Hg}$ and $\mathrm{U}$ have no known vital or beneficial effect in living organisms' bodies, and their accumulation over time in our bodies can cause serious adverse health effect.

The iron content in sugar apple was $1.27 \pm 0.54 \mathrm{mg} / 100$ $\mathrm{g}$-fw a value less than the level $4.81 \mathrm{mg} / 100 \mathrm{~g}$-fw for Indian sugar apple fruits [4]. and the level of $1.70 \pm 0.05 \mathrm{mg} / 100 \mathrm{~g}$ for Nigerian sugar apple fruits [32]. The contribution of iron by this fruits in the diet is poor as the range obtained in this study is less than the range for the RDA of $8.0-20 \mathrm{mg} / \mathrm{day}$ [45]. Iron is an essential element for almost all living organisms as it participates in a wide variety of metabolic processes, including oxygen transport, deoxyribonucleic acid (DNA) synthesis, and electron transport. However, in excessive amounts, it can lead to tissue damage [46]

The average copper content in sugar apple was $0.12 \pm 0.07$ $\mathrm{mg} / 100 \mathrm{~g}$-fw. The level of copper measured in this study can be compared to the level of copper in sugar apple from other countries such as India $0.95 \mathrm{mg} / 100 \mathrm{~g}$, fw [4] and Nigeria 0.02 $\pm 0.00 \mathrm{mg} / 100 \mathrm{~g}$-fw [32]. When the level of copper was compared to the RDA level of $1.2-3.2 \mathrm{mg} / 100 \mathrm{~g}$ for copper in foods, sugar apple fruits had levels below this value.

The level of zinc content in sugar apple fruits was $0.51 \pm$ $0.10 \mathrm{mg} / 100 \mathrm{~g}$-fw slightly higher when compared to other Tanzanian fruits studied such as soursop $0.32 \pm 0.09 \mathrm{mg} / 100$ $\mathrm{g}$-fw [9] and pomegranate $0.45 \pm 0.10 \mathrm{mg} / 100 \mathrm{~g}$-fw [10]. Since there were no major existing industries in Kibaha, it is assumed that the sources contributing zinc were probably from motor vehicles tire rubber exacerbated by poor road surfaces and the lubricating oils in which $\mathrm{Zn}$ is found as part of many additives such as zinc dithiophosphates [47]. However, the levels of zinc in these fruits compares well to the level of zinc in sugar apple fruits from Nigeria $0.30 \pm 0.02 \mathrm{mg} / 100$ g-fw [32] but less than the value $2.868 \mathrm{mg} / 100 \mathrm{~g}$-fw reported for Indian sugar apple fruits [4] and $300 \mathrm{mg} / 100 \mathrm{~g}$-fw reported by Amoo et al. [31]. When the zinc levels found were compared to the FAO and WHO permissible level of zinc in foods ( $6 \mathrm{mg} / 100 \mathrm{~g}$-fw) [48] these fruits had levels well below this permissible level.

Cadmium was below the detected limit, an observation similar to that reported by Othman et al. [9] for soursop from Coast Region and Lugwisha et al. [10] for pomegranate from Dar es salaam, Tanzania. Bhardwaj et al. [4] reported a value $<0.0017 \mathrm{mg} / 100 \mathrm{~g}$-fw for Indian sugar apple fruits which is a very low value. The low amount of cadmium in these fruits can probably be due to the sampling area being away from non ferrous metal production, fossil fuel combustion, waste incineration and iron and steel production which are the main sources of cadmium to the soil.

The average concentration of lead in sugar apple was $0.13 \pm$ $0.03 \mathrm{mg} / 100 \mathrm{~g}$-fw. This level cannot lead to any health hazard to consumers since it is lower than the maximum permissible limit of $3 \mathrm{mg} / 100 \mathrm{~g}$-fw lead and thus falls within safe limits for consumption stated by FAO/WHO [48].

\section{Conclusion}

The physicochemical composition of sugar apple (Annona squamosa L.) fruits from Kibaha, Coast Region during open air storage ripening process were determined. Changes in proximate composition (ash, titratable acidity, crude fat, crude fibre, moisture and sugars content), ascorbic acid level, macro-nutrients and heavy metals contents during the storage ripening process were obtained. The soursop fruits had high moisture content $(64 \%-73 \%)$, low titratable acidity $(<0.28 \%$ ca), low crude fat $(0.51 \mathrm{~g} / 100 \mathrm{~g}$-fw $)$, high ash content $(1.44$ 
g/100 g-fw), low crude fibre content (0.185 g/100 g-fw), high ascorbic acid content ( $51-34 \mathrm{mg} / 100 \mathrm{~g}$-fw), high total sugars content $(49.7 \%-31.1 \%)$, moderate reducing sugar content $(43.17 \%-18.57 \%)$ and sucrose content $(11.8 \%-0.9 \%)$. Of the macro-elements $\mathrm{K}, \mathrm{Ca}$ and $\mathrm{Na}$ determined, the highest level was of $\mathrm{Ca}$ i.e. $2838.82 \mathrm{mg} / 100 \mathrm{~g}$-fw. Heavy metal concentrations in the sugar apple fruits were very low indicating insignificant pollution of the fruits. The moisture content, total sugar content, reducing sugar content and sucrose increased during the storage ripening period. The titratable acidity and ascorbic acid content decreased as the fruit was ripening while in storage. Comparison of our results and FAO/WHO standards reveals that this fruit from Coast, Region, Tanzania can play the valuable role of fulfilling daily human diet needs as well as a health nutrient supplement.

\section{Acknowledgement}

The authors would like to acknowledge financial assistance from Quality Enhancement of College Teaching Education (QECTE) through Mkwawa University College of Education, Iringa, Tanzania. They also express their gratitude to the Chemistry Department, University of Dar es Salaam, for providing the laboratory facilities.

\section{References}

[1] Tien, Y. Y., Chang, C. C., Sheng, W., Kotwal, S. and Tay Shyu, Y., Studies on the lactic-fermentation of sugar apple (Annona squamosa L.) puree. J. Food and Drug Anal. 13, 2005, p. 377-381.

[2] Orsil, D. C., Carvalho, V. S., Nishi, A. C. F., Damiani, C. and Asquieri, E. R., Use of sugar apple, atemoya and soursop for technological development of jams - chemical and sensorial composition. Ciênc. agrotec. vol.36 (5), 2012.

[3] Cavalcante, Í. H. L., Cavalcante, L. F., Miranda, J. M. and Martins, A. B. G., Physical and chemical characteristics of tropical and non-conventional fruits in "food industrial processes - methods and equipment" edited by Dr. Benjamin Valdez. 2012. Publisher In Tech.

[4] Bhardwaj, A., Satpathy, G. and Gupta, R. K., Preliminary screening of nutraceutical potential of Annona squamosa, an underutilized exotic fruit of India and its use as a valuable source in functional foods. Journal of Pharmacognosy and Phytochemistry. 3 (2), 2014, p. 172-180.

[5] Pandey, D. and Barve N., Phytochemical and pharmacological review on Annona squamosa Linn. Int. J Res. in Pharm. and Biomed. Sci. 4, 2011, p. 1404-1412.

[6] Othman, O. C. and Mbogo, G. P., Physico-chemical characteristics of storage-ripened mango (Mangifera indica $\mathrm{L}$.) fruits varieties of eastern Tanzania. Tanz. J. Sc. 35, 2009, p. 5765 .

[7] Othman, O. C., Physical and chemical composition of storage-ripened papaya (Carica papaya L.) fruits of Eastern Tanzania. Tanz. J. Sci. 35, 2009, p. 47-55.

[8] Othman, O. C., Physicochemical characteristic inorganic elements in off-vine ripened pineapple (Ananas comosus L.) fruits of Dar es Salaam, Tanzania. KIST. Journal of Science and Technology. 1, 2011, p. 23-30.

[9] Othman, C. O., Fabian, C. and Lugwisha, E., Post harvest physicochemical properties of soursop (Annona muricata L.) fruits of Coast region, Tanzania. Journal of Food and Nutrition Sciences. Vol. 2, No. 5, 2014, p 220-226.

[10] Lugwisha, E. H., Fabian, C. and Othman, O. C., Determination of physico-chemical properties of pomegranate (Punica granatum L.) fruits of Dar es Salaam Tanzania. Journal of Food and Nutrition Sciences. Vol. 2, No. 6, 2014, p. 277-284.

[11] Mbogo, G. P., Mubofu, E. B. and Othman, O. C., Postharvest changes in physical-chemical properties and levels of some inorganic elements in of vine ripened orange (Citrus sinensis) fruits $\mathrm{Cv}$ (Navel and Valencia) of Tanzania. Afr. J. Biotechnol. 35, 2010, p. 58-66.

[12] Sobukola, O. P., Adeniran, O. M., Odedairo, A. A. and Kajihausa, O. E., Heavy metal levels of some fruits and leafy vegetables from selected markets in Lagos, Nigeria. African Journal of Food Science. Vol. 4(2), 2010, p. 389-393.

[13] Usman, H., Abdulrahman, F. I., Kaita, A. H. and Khan, I. Z., Proximate and elemental composition of Bauhinia rufescens Lam (Leguminosae: Caesalpinioidaea). Int. J. Biol. Chem. Sci. 5(4), 2011, p. 1746-1753.

[14] Colak, H., Soylak, M. and Turkoglu, O., Determination of trace metal content of various herbal and fruit teas produced and marketed from Turkey. Trace Elements and Electrolytes. 22, 2005, p. 192-195.

[15] Ranganna, S., Manual of analysis of fruit and vegetable products. Tata MacGraw Hill Company Ltd, New Delhi. 1977, p. 21-60.

[16] AOAC Association of official analytical chemists. Official methods of analysis of the association of official analytical chemists. Arlington VA. 1990, p. 1230.

[17] Nwofia, G. E., Nwogwu, N. and Nwofia, K. B., Nutritional variations in fruits and seeds of pumpkins (Cucurbita Spp); Accessions from Nigeria. Pakistanian Journal of Nutrition. 11(10), 2012, p. 848-858.

[18] Bolivar, F. N., Saucedo, V. C., Solis, P. S. and Sauri, D. E., Ripening of sugar apple fruits (Annona squamosa L.) developed in Yucatan, Mexico. Agrociencia. 43, 2009, p. 133-141.

[19] Carey, D. M. and Nao, S. W., Composition of Hawaii fruits, Hawaii agricultural experimental stations. University of Hawaii. 1965, pp. 21.

[20] Nagar, P. K., Effects of some ripening retardants on fruit softening of enzymes of Kinnow mandarin fruits. Ind. J. plant physiol. 37, 1994, p. 122-124.

[21] Vishnu, K. N., Sudhaka, D. V. and Krishnamurthy, S., Effect of storage temperature on ripening and quality of custard apple (Annona squamosa L.) fruits. J. Hortic. Sci. and Biotechnol. 75, 2000, p. 546-550.

[22] Maiman, S. A. and Ahmad, D., Changes in physical and chemical properties during pomegranate (Punica granatum L.) fruit maturation. J. Food Chem. 76, 2001, p. 437-441. 
[23] Sravanthi, T., Kavitha, W. and Jayasimha, R. D., Studies on preservation and processing of custard apple (Annona squamosa L.) pulp. International Journal of Plant, Animal and Environmental Sciences. Vol 4 (3), 2014, p. 676-682.

[24] Juceliandy, S. P., Gisele, P. M., Edson, H. M., Bárbara, N. S., Maria, H. M., Maryelle, C. A., Darlaine, M. F., Wagner, FM and Victor, M. M., Maturation control of sugar apple using 1 methylcyclopropene, modified atmosphere packaging and cooling. J. Food, Agric. and Environ. 10, 2012, p. 217-220.

[25] Trang, S. T., Nguyen Thi, H. P. and Willem, F. S., Protective effect of chitosan coating and polyethylene film wrapping on postharvest storage of sugar-apples. As. J. Food Ind. 4, 2011, p 81-90.

[26] Pinto, A. C., Cordeiro, S. R., Ferreira, F. R., Filgueirs, H. A., Alves, R. E. and Kimpara, D. I. Annona species. International centre of underutilized crops University of Southampton. 2005, p. 39.

[27] Martínez Maldonado, F. E., Lasprilla1, D. M., Magnitskiy, S. and Melgarejo, L. M., Germination, protein contents and soluble carbohydrates during storage of sugar apple seeds (Annona squamosa L.) Journal of Applied Botany and Food Quality. 88, 2015, p. 308-313.

[28] Pareek, S., Yahia, E. M., Pareek, O. P. and Kaushik, R. A., Postharvest physiology and technology of annona fruits. Food res. Int. 44, 2011, p. 1741-1751.

[29] $\mathrm{FAO} / \mathrm{WHO}$, Expert consultation on human vitamins and minerals requirement. Bangkok-Thailand. 1998, p. 130-139.

[30] Coke, J. R. and Moxon, R., Vitamin C (ascorbic acid). Applied Science London and New York Jersey. 1982, p. 121-134.

[31] Amoo, I. A., Emenike, A. E. and Akpambang, V. O. E., Compositional evaluation of annona chermoya (custard apple) fruit. Trends in applied Sciences Research. 3(2), 2008, p. 216-220.

[32] Hassan, L. G., Muhammad, M. U., Umar, K. J. and Sokoto, A. M., Comparative study on the proximate and mineral contents of the seed and pulp of sugar apple (Annona squamosa L.) Nigerian Journal of Basic and Applied Sciences. vol. 16 No. 2, 2008, p. 179-182.

[33] Lokhande, A. R., Patil, V. S. and Wani K. S., Study of Diethanolamide from Custard Apple Seed Oil (Annona squamosa L.). International Journal of Engineering Research \& Technology. Vol. 2 Issue 9, 2013, p. 448-452.

[34] Mariod, A. A. and Ahmed, Y. M. Annona squamosa and catunaregam nilotica seeds, the effect of the extraction method on the oil composition. J Am Oil Chem. Soc. Vol. 87, 2010, p. 763-769.

[35] Shardul, K., Swati, J, Prajakta, K., Prafullachandra, T., Santosh P. and Arun, R., Proximate analysis of peel and seed of Annona squamosa (custard apple) fruit. Research Journal of Chemical Sciences. Vol. 3(2), 2013, p. 92-94.

[36] Minh, N. P., Different factors affecting to custard apple Annona squamosal wine fermentation. International Journal of Multidisciplinary Research and Development. 1(6), 2014, p. 165-167.

[37] Muteti, M. N., Application of grape wine production protocol to produce custard apple wine. Project Report. 4th Year B.Sc. Food science and technology. Department of food science, nutrition and technology. Faculty of agriculture. College of agriculture and veterinary science. University of Nairobi. 2008.

[38] Leal, F., Nagy, P., Shaw, S. and Wardowski, W. F., Tropical and sub tropical fruits, composition, properties and uses. Florida, Florida Science Sources Inc. 1990, p. 149-158.

[39] Narian, N., Bora, P. S., Holschuh, H. J. and Vasconcelos, M. A., Physical and chemical composition of carambola fruits (Averrhoea carambola L.) at three stages of maturity. Cienc. Tecno. Aliment. 3, 2001, p. 144-148.

[40] Duncan, K. H., Bacon, J. A. and Weinsier, R. L., The effects of high and low energy density diets on society, energy intake, and eating time of obese and nonobese subjects. Am. J. Clin. Nutr. 37, 1983, p. 763-767.

[41] Punna, R. and Paruchuri, U. R., Total insoluble and soluble dietary fiber contents of Indian fruits. J. Food Comp. Anal. 16, 2003, p. 677-685.

[42] Howarth, N. C., Saltzman, E. and Roberts, S. B., Dietary fiber and weight regulation. Energy density of foods affects energy intake across multiple levels of fat content in lean and obese women. Am. J. Clin. Nut. 73, 2001, p. 1010-1018.

[43] Siddhurju, P., Vijayakumari, K. and Janardhanan, K., Fibers in fruits. J. Food Chem. 3, 1996, p. 385-389.

[44] Carolina, H., Sergio, A., Italo, C., Tania, V., Manuel, A., Lorena, C., Ricardo, S. and Hernán, S., Determination of antioxidant capacity, total phenolic content and mineral composition of different fruit tissues of five apple cultivars grown in chile. Chilean J. Agric. Res. 70, 2010, p. 523-536.

[45] National Research Council NRC., USA recommended Dietary Allowances Washngton, DC, National Academy press. 1989, p. 42.

[46] Abbaspour, N., Hurrell, R. and Kelishadi, R., Review on iron and its importance for human health. Journal of Research in Medical Sciences. 19(2), 2014, p. 164-174.

[47] Jaradat, Q. M. and Moman K. A., Contamination of roadside soil, plants and air with heavy metals in Jordan, A comperative study. Turk. J. Chem. 23, 1999, p. 209-202.

[48] Commission, Codex Alimentarius, Food additives and contaminants. Joint FAO/WHO Food standards programme. 2001, p. 1-289. 